\title{
PSRS MILITĀRAS NOZĪMES INFRASTRUKTŪRAS IZPĒTE LATVIJAS TERITORIJĀ
}

\section{Juris Paiders}

Latvijas Universitāte, G̦eogrāfijas un Zemes zinātṇu fakultāte, e-pasts: jpaiders@inbox.Iv

Anotācija. Jautājumi par padomju militārā mantojuma objektiem, to militāro nozīmi, iekḷaušanu un izmantošanu mūsdienu kontekstā ir plaši apskatîti zinātniskajā literatūrā, tomēr Latvijā pieejamie atslepenotie avoti tikai nosacīti atsedz dažādu militāru objektu specializāciju Aukstā kara laikā. Darbā tiek vērtēti dažādi informācijas avoti par PSRS militāro infrastruktūru Aukstā kara laikā - atklātos izdevumos publicētā informācija, publicētā un klasificētā statistika, PSRS ǵenerālštāba topogrāfiskās kartes u.c. ASV izlūkdienestu atslepenotā informācija u.c. materiāli. Darbā tiek secināts, ka, ņemot vērā cenzūras ierobežojumus, padomju laika atklātos iespieddarbos publicētajos materiālos nav nozīmīgas informācijas, ko varētu izmantot, lai novērtētu PSRS militārās sfēras mērogu un militārā sektora ietekmi uz ekonomikas attīstību. Padomju laika PSRS G̣enerālštāba topogrāfiskās kartes pilnībā neatklāj informāciju par PSRS 
militāro objektu izvietojumu. Nozīmīgi avoti PSRS militārās infrastruktūras izpētē ir ASV atslepenotā informācija 1994.-1997. gada ortofoto attēli un Latvijas topogrāfiskā karte mērogā 1:10 000.

Atslēgas vārdi: PSRS militārās bāzes, klasificēta informācija, slepena informācija, topogrāfiskās kartes, cenzūra.

\section{Ievads}

Pēc 2. pasaules kara PSRS militārās bāzes aizṇēma 10\% Latvijas kopējās platības un bija izvietotas 600 dažādās vietās (Burlakovs, Vircavs 2011). Militārā sektora patēriņa daḷa PSRS iekšzemes kopproduktā, kas lielā mērā attiecināma arī uz Latvijas tautsaimniecību, 20. gadsimta 80 . gadu vidū tiek vērtèta no $18,8 \%$ līdz pat $30 \%$ (Simonov 2015). Militārā sektora nozīmes novērtējums joprojām ir apgrūtināts pat tad, ja pētniekiem ir pieejama PSRS laika slepenā statistika, jo norēkinos par piegādāto produkciju PSRS militārā rūpniecība maksāja 3-4 reizes zemākas cenas par tām, kas tika maksātas civilajā sektorā (Simonov 2015). Informācija par tiem PSRS armijas objektiem, kas tika atgūti pēc Latvijas neatkarības atjaunošanas, ir visai detalizēta un zināma (Upmalis et al. 2006; Upmalis et al. 2011). Tomēr dokumentācija par padomju armijas izvešanu no Latvijas teritorijas neatklāj to, kas tika izvests no Latvijas līdz 1991. gadam un tikai nosacīti atsedz dažādu militāru objektu specializācijas maiṇu Aukstā kara laikā.

Jautājumi par padomju militārā mantojuma objektiem, to militāro nozīmi, iekḷaušanu un izmantošanu Austrumeiropā un bijušajās padomju republikās mūsdienu kontekstā ir plaši apskatîti zinātniskajā literatūrā (Harrison 2012; Jarv et al. 2013 u.c.). Latvijā, pētot informāciju, kas PSRS laikā bija slepena vai īpaši slepena, ir plaši veikta arī ar PSRS Valsts Drošības komiteju saistīto un agrāk slepeno dokumentu zinātniskā izpēte (Jansons 2003; Bergmanis, Zālīte 2004; Stukāns et al., 2016 u.c.). Tā kā Latvijas arhīvos maz ir saglabājies LPSR VDK centrālā "aparāta" svarīgāko organizatorisko un pastāvīgo darbību reglamentējošo dokumentu (Zelmenis 2015 u.c.), tad īpaši tiek aplūkota pieeja PSRS laika slepeno dokumentu izpētei (Jansons 2005 u.c.) Diemžēl pētnieki var izmantot tikai nedaudz PSRS drošības iestāžu pavēḷu, jo atslepenotas un publicētas ir tikai dažas no tām. Pilnīgi visas PSRS drošības iestāžu pavēles atrodas vienīgi Krievijas Federālā drošības dienesta arhīvā, un tās joprojām ir slepenas (Jansons 2016), tāpēc zinātniskā izpēte jāveic, izmantojot pieejamos arhīvu materiālus.

Diemžēl pagaidām nav informācijas, ka Latvijas rīcībā būtu daudz PSRS laika slepeno vai īpaši slepeno dokumentu par PSRS militarizācijas apmēriem, militārajiem plāniem utt. Ja neņem vērā dažas publikācijas (Krūmiņš 2012; Krūmiņš 2017), tad padomju laika militarizācijas apmēru izvērtējums Latvijā tiek apskatīts visai reti.

Informācijas slepenības ietekme uz statistikas un kartogrāfiskajiem avotiem

PSRS laikā informācija tika sadalīta atbilstoši tās atḷautajam izmantošanas veidam. Zemākais slepenības līmenis bija "Dienesta lietošanai" (ДСП - Для служебного пользования), kas ietvēra plānošanas vai valsts civilās pārvaldes vajadzībām nepieciešamo informāciju, kuru bija aizliegts publicēt atklātos iespieddarbos. Uzraksts "slepeni”" nenozīmēja, ka attiecīgajā dokumentā patiešām ir 
valsts noslēpums. Statuss "slepeni" tika lietots tiem dokumentiem, ar kuru palīdzību varēja identificēt, piemēram, slepenu objektu atrašanās vietu. Ar klasifikāciju "slepeni" tika marķēti arī dokumenti, kuru saturs bija pretrunā ar oficiālajiem vērtējumiem vai ideologiskajām dogmām.

Savukārt neklasificētā - brīvi pieejamā - informācija tika nošḳirta publicējamā un nepublicējamā informācijā. Publicēšanai aizliegto tēmu, objektu un informācijas sarakstu noteica PSRS Galvenās pārvaldes instrukcijas valsts noslēpumu aizsardzībai atklātos iespieddarbos (PSRS atklātajos 2008; Atklātajos iespieddarbos 1976 u.c.), kas tika regulāri atjauninātas un bija klasificētas kā slepenas.

Nepublicējama informācija, kas netika klasificēta ar zemāko slepenības līmeni “dienesta lietošanai" - bija atklāta, bet to bija aizliegts publicēt. Publicējamai informācijai bija vairāki izplatīšanas līmeņi. Cenzūras aizliegumi pakāpeniski, līdz pat 1989. gada februārim, kad tika sākta pakāpeniska atteikšanās no cenzūras, tika palielināti.

Publicētās tautsaimniecības statistikas vajadzībām tika atlasīti dati vai to matemātiskie aprēḳini (pieauguma procenti), kas bija derīgi propagandas un ideoloǵijas vajadzībām un neatklāja padomju militārā vai ekonomiskā potenciāla vājās puses. Padomju laikā publicētajiem statistikas krājumiem bija jāṇem vērā visi cenzūras ierobežojumi, līdz ar to padomju laikā publicētie statistikas krājumi neatsedz nedz militāra sektora izvietojumu, nedz militāro patēriṇu pat apkopotā formā. Militārās rūpniecības vai militārā sektora patēriṇa apjomi nav iegūstami arī no statistiskas krājumiem, kas bija klasificēti dienesta lietošanai. Statistika "dienesta lietošanai" bija paredzēta plānošanas un pārvaldes (tostarp militāras pārvaldes) vajadzībām, un to publicēt bija aizliegts. Sal̄̄dzinot līdzīgu datu apjomu klasificētiem (Statistikas biḷetens 1986 u.c.) un publicētiem (Latvijas PSR 1987 u.c.) statistikas datiem, var secināt, ka informācija pamatā sakrīt. Publicētājā statistikā neiekḷāva datus, kas nevairoja optimismu, liecināja par negatīvām tendencēm utt. Šī informācija tika iekḷauta tikai statistikas krājumos, kas bija paredzēti dienesta lietošanai.

Padomju slepenās militārās kartogrāfijas zinātniskā izpēte vairāk ir fokusējusies uz to, kā Rietumvalstu militārie un stratēǵiskie objekti tika dešifrēti un atainoti padomju topogrāfiskajās kartēs (Kent, Davies 2013; Davies, Kent, 2017 u.c.). Lai gan uz PSRS civilajiem mērḳiem lietotajām PSRS G̣enerālštāba topogrāfiskajām kartēm bija uzraksts "slepeni”, tajās nebija informācijas, kas būtu klasificēta kā valsts noslēpums. PSRS G̣enerālštāba topogrāfiskajās kartēs parasti nenorādīja un neidentificēja militāros objektus, pretgaisa aizsardzības sistēmas ēkas un būves, militāros lidlaukus un pat civilo lidlauku konfigurāciju. Šādas informācijas izpaušana ārvalsts pārstāvim PSRS Kriminālkodeksā tika klasificēta kā smagākais iespējamais noziegums - Dzimtenes nodevība. PSRS Kriminālkodeksa 59. pants Dzimtenes nodevība par valsts vissvarīgāko militāro noslēpumu definēja pat "vispārinātus datus par lidlauku tīklu, par to kvalitātes stāvokli un lidlauku uzṇemšanas spējām" (Vìtols 1965).

2015. gada 22. decembrī ASV Nacionālās drošības arhīvs (National Security Archive) publiskoja 1959. gadā sagatavoto ASV kodolmērķu sarakstu (SAC Atomic 1959), kurā ir norādīti svarīgākie militārie mērḳi un to geoogrāfiskās koordinātes. 
Gatavojoties iespējamai militārai konfrontācijai ar PSRS, militārie mērḳi tika sagrupēti to svarīguma secībā. Vissvarīgākais mērḳis Latvijas teritorijā ir apzīmēts ar „Rīga rietumi” (56 grādi 55 minūtes ziemeḷu platums un 23 grādi un 59 minūtes austrumu garums), kura koordinātes aptuveni sakrīt ar pašreizējās lidostas Rìga novietojumu, un tam iznīcināšanas secībā bija 149. kārtas numurs. Spilves lidlaukam bija 191. kārtas numurs utt. ASV publiskotajā PSRS teritorijā esošo militārās aviācijas mērḳu sarakstā ir norādīti 16 mērḳi (norādot ǵeogrāfiskās koordinātes līdz pat minūtei), kas tika identificēti kā militāras vai dubultās noz̄mes lidlauki. No tiem PSRS Ģenerālštāba topogrāfiskajās kartēs vispār nebija norādīti nedz Spilves, nedz Rumbulas, nedz Jēkabpils, kā arī Vaiṇodes, Ventspils un pārējie lidlauki. Četrpadsmit no sešpadsmit 1959. gadā iespējamiem lidlaukiem vai aviācijas bāzēm Latvijas teritorijā varēja identificēt, izmantojot 90. gadu sākumā izdoto Latvijas topogrāfisko karti mērogā 1:10 000 (Topokarte, bez datējuma) un Latvijas 1. posma ortofoto kartes (VZD Latvijas bez datējuma). Vienīgais lidlauks, kuru no 20. gadsimta septiņdesmito gadu vidus sāka attēlot PSRS G̣enerālštāba topogrāfiskajās kartēs mērogā 1:50 000, bija lidosta Rīga (Bijušās PSRS 42 bez datējuma). No 2017. gada sākuma ir brīvi pieejami vairāki miljoni ASV Centrālās izlūkošanas pārvaldes (CIP) agrāk slepeno dokumentu, kuros ar izlūkošanas pavadoṇu uzņemto fotoattēlu palīdzību bija identificējami militārie un militāras nozīmes industriālie objekti PSRS teritorijā.

PSRS laikā publicētās kartes nevar tikt izmantotas kā avots korektai tautsaimniecības un militārā sektora ğeogrāfijas izpētei, jo slepenās instrukcijas par atklātajos iespieddarbos, radio un televīzijas raidījumos publicēšanai aizliegtajiem datiem 1970. gada redakcijas 67. paragrāfa 2.d. un 1976. gada redakcijas 70. paragrāfa 2.d. aizliedza publicēt PSRS teritorijas kartes jebkurā mērogā, ja tajās bija atzīmēti “aizsardzības rūpniecības uzņēmumi, militārie un citi slēgtie objekti" (PSRS atklātajos 2008; Atklātajos iespieddarbos 1976). Visām pēc 1964. gada atklātajos iespieddarbos publicētajām kartēm precizitāte nedrīkstēja pārsniegt PSRS oficiālās 1:2 500000 mēroga kartes precizitāti (PSRS atklātajos 2006; Atklātajos iespieddarbos 1976). No 1976. gada bija aizliegts ar atsauci vai jebkādā citā veidā norādīt, ka visās publicētajās kartēs tiek izmantota PSRS oficiālā 1:2 500000 mēroga kartes pamatne (Atklātajos iespieddarbos 1976). Pilsētu (un ciematu) plānos bija aizliegts parādīt militāros un rūpniecības objektus, noliktavas un tamlīdzīgas celtnes, koordinātes un ǵeogrāfiskos tīklus. Pilsētu un ciemu plānojumu bija atḷauts parādīt tikai shematiski (Atklātajos iespieddarbos 1976).

Pēc tam, kad plaši sāka lietot no kosmosa veiktos fotouzṇēmumus, PSRS lielākoties pārtrauca praksi nenorādīt uz topogrāfiskajām kartēm ēku grupas. Tās, kas bija dabā, bet nebija attēlotas topogrāfiskajās kartēs, varētu radīt pretiniekā interesi noskaidrot, vai tie ir kādi īpaši slepeni militāri objekti. Aptuveni no 20.gs. 60. gadu beigām PSRS topogrāfiskajās kartēs dažkārt tika attēlotas no satelītu uzṇēmumiem vizuāli identificējamas militāras nozīmes ēkas, par kurām tika sniegta maldīga informācija, uzdodot tās par civilas nozīmes ēkām. Piemēram, Dobeles tuvumā izvietotā 24. tanku divīzijas bāze (mūsdienās Gardene), kas tika uzcelta 20.gs. 60. gadu sākumā, 
PSRS topogrāfiskajā kartē mērogā 1:50 000 (karte tiek klasificēta kā slepena), kas tika izdota 1975.-1977.g., Dobele 2 êku kontūras tika apzīmētas kā meža izstrādātāju ciemata (leshoz) ēkas (Bijušās PSRS bez datējuma).

Iespējama kara gadījumam PSRS militārās kartes tika glabātas divdesmit piecās militāro karšu krātuvēs (Davies 2005b). Slepenās kartes, kas glabājās Baltkrievijas, Krievijas un Ukrainas teritorijā, nonāca Krievijas kontrolē (Davies 2005b), savukārt Latvijas krātuvē glabājās aptuveni 6000 tonnu slepeno militāro karšu, kuras 1992.g. tika pavēlēts iznīcināt. No iznīcināšanai nolemtā apjoma vairākas tonnas slepeno kartogrāfisko materiālu nonāca privātā apritē (Davies 2005b). Visticamāk, ka līdz 1992. gadam PSRS militāro karšu krātuvēs tika veikta slepeno materiālu nošķiršana, pārvietojot uz Krieviju vai pilnībā iznīcinot Krievijas pilsētu detalizētos topogrāfiskos plānus mērogā 1:10 000 un 1:25 000, jo 2005. gadā nevienā Lielbritānijas karšu kolekcijā nebija PSRS topogrāfisko karšu, kurās būtu attēlota kaut viena Krievijas pilsēta šādā detalizētā mērogā (Watt 2005).

\section{Secinājumi}

N̦emot vērā cenzūras ierobežojumus, padomju laika atklātajos iespieddarbos publicētajos materiālos nav nozīmīgas informācijas, kas būtu izmantojama, lai novērtētu PSRS militārās sfēras mērogu un militārā sektora ietekmi uz ekonomikas attīstību.

Ṇemot vērā militāro objektu attēlošanas ierobežojumus, padomju laika PSRS G̣enerālštāba topogrāfiskās kartes neatklāj informāciju par PSRS militāro objektu izvietojumu.

Viens no nozīmīgākajiem avotiem PSRS militārās infrastruktūras un divējādās nozīmes objektu identifikācijai ir PSRS armijas objektu pārṇemšanas dokumentācija, uzreiz pēc Latvijas neatkarības atgūšanas veiktie ortofoto attēli un izdotā Latvijas topogrāfiskā karte mērogā 1:10 000 .

Arvien lielāku nozīmi PSRS militārās infrastruktūras un divējādās nozīmes objektu identifikācijā un to nozīmes maiṇā (Aukstā kara laikā) iegūst ASV atslepenotā informācija par svarīgākajiem PSRS militārās nozīmes objektiem Latvijā.

\section{Izmantotā literatūra}

Atklātajos iespieddarbos, radio un televīzijas raidījumos publicēěsanai aizliegto datu saraksts. (1976). Maskava, PSRS Galvenā pārvalde valsts noslēpumu aizsardzībai atklātos iespieddarbos. [Перечень сведений, запрещенных к опубликованию в открытой печати, в передачах по радио и телевидению. Москва, Главное управление по охране государственных тайн в печати при Совете Министров СССР]

Bergmanis, A., Zālīte, I. (2004) Okupācijas varas represīvā sistēma: Latvijas PSR Valsts drošības komitejas darbība (1953 - 1959). Okupācijas režīmi Latvijā 1940. - 1959. gadā, Latvijas Vēsturnieku komisijas raksti, 10. sēj. Rīga: Latvijas vēstures institūta apgāds, 373. - 432.

Bijušās PSRS armijas G̦enerālštāba 42. gada sistēmas topogrāfisko karšu mozaīka mērogā 1:50 000. LU ĢZZF karšu pārlūks http://kartes.geo.lu.lv/karte/ (26.01.2018.)

Burlakovs, J., Vircavs, M. (2011) Possible Applications of Soil Remediation Technologies in Latvia. Scientific Journal of Riga Technical University. Environmental and Climate Technologies, 7. 46. - 53.

Davies, J. (2005a). Uncle Joe knew where you lived. The story of Soviet ma pping of Britain (part I). Sheetlines, 72, $26-38$. 
Davies, J. (2005b). Uncle Joe knew where you lived. Soviet mapping of Britain (part 2). Sheetlines, $73,6-20$

Davies, J., Kent, A. J. (2017). The Red Atlas: How the Soviet Union Secretly Mapped the World. Chicago, University of Chicago Press.

Harrison, F. W. (2012). Reviving Heritage in Post-Soviet Eastern Europe: A Visual Approach To National Identity, The University of Western Ontario Journal of Anthropology, 20(1), 1- 15. Available at: http://ir.lib.uwo.ca/totem/vol20/iss1/3

Jansons, R. (2003), Totalitāro režīmu represīvo institūciju mijiedarbība un nozīme sabiedrības pārvaldē Latvijas PSR (1944 - 1959), Totalitārie okupācijas rě̌īmi Latvijā 1940. - 1964. gadā, Latvijas Vēsturnieku komisijas raksti, 13. sēj., Rīga: Latvijas vēstures institūts, 442 - 488.

Jansons, R. (2005). Latvijas PSR drošības iestāžu vēstures pētīšanas rezultāti un perspektīvas, Totalitārie režīmi Baltijā: izpētes rezultāti un problēmas, Latvijas Vēsturnieku komisijas raksti, 15. sējums. Rīga: Latvijas vēstures institūts, $211-224$.

Jansons, R. (2016). LPSR drošības iestāžu darbība 1944. - 1956. (ziñojumi starptautiskajā zinātniskajā konferencē Totalitārisma sabiedrības kontrole un represijas: dokumentu izpēte un tās metodologija 2015. gada 15. - 17. decembrī Liepājā. Jarinovska K. (red.) VDK zinātniskās izpētes komisijas raksti, 2. sēj. Rīga: LPSR Valsts drošības komitejas zinātniskās izpētes komisija, Latvijas Universitātes Latvijas vēstures institūts.

Järv, H., Raukas, A., Sepp, K., Raet, J. Ward R. D. (2013). Soviet Military Heritage: Brown And Green - Recovery And Enhancement. WIT Transactions on The Built Environment, 131, 579 - 592.

Kent, A. J., Davies, J. (2013). Hot geospatial intelligence from a Cold War: the Soviet military mapping of towns and cities. Cartography and Geographic Information Science. 40(3), 248 - 253.

Krūmiņš, G. (2017). Latvijas tautsaimniecība (1960-1985). Latvijas tautsaimniecības vēsture (Sast.) Krūmiņš G. Rīga: Jumava, 287 - 312.

Krūmiņš G. (2012). Tautsaimniecība un naudas politika Latvijā (1945-1991). Latvijas Bankai XC. Rīga: Latvijas Banka, 111 - 134.

Latvijas PSR (1987). Latvijas PSR tautas saimniecība 1986.g., Rīga: Avots

PSRS atklātajos iespieddarbos, radio un televīzijas raidījumos publicēšanai aizliegto datu saraksts. Slepeni. 1. eksemplārs. Maskava, 1970. (2008) Dokumentu krājums. (Sast.) Strods H.. Rīga: SIA Triple Bounce

SAC Atomic Weapons Requirements Study for 1959, U.S. (1959). National Archives, College Park, Record Group 242, Operational Planning, box 147, file B 89351. http://nsarchive.gwu.edu/nukevault/ebb538-Cold-War-Nuclear-Target-List-Declassified-First-Ever/ (26.01.2018)

Simonov, N. (2015). PSRS Militāri rūpnieciskais komplekss: ekonomiskās izaugsmes tempi, struktūra, ražošanas organizācija, vadība [Симонов Н.С. ВПК СССР: темпы экономического роста, структура, организация производства, управление. М.: Русский Фонд Содействия Образованию и Науке]

Statistikas bil̦etens (1986). Статистический бюллетень, 1(167), Часть 1, январь 1986. Рига: Центральное статистическое управление Латвийскои ССР.

Stukāns, J., Krūmiņa-Koṇkova, S., Daukste-Silasprog̊e, I., Dātavs, M., Ķeruss, J., Krēsliņš, U., Ērglis, Dz., Brūnava, M., Starostina, M., Žvinklis, A., Kangeris, K. (2016). Lielais brālis tevi vēro: VDK un tās piesegstruktūras. Ziņojumi starptautiskajā zinātniskajā konferencē 2016. gada 11.-13. augustā Rīgā. Jarinovska K. (red.) VDK zinātniskās izpētes komisijas raksti, 3. sēj. Rīga: LPSR Valsts drošības komitejas zinātniskās izpētes komisija, Latvijas Universitāte.

Topokarte M1:10 000, Latvijas G̦eotelpiskās informācijas aǵentūra LU G̣ZZF karšu pārlūks. http://kartes.geo.lu.lv/karte/ (26.01.2018)

Upmalis, I., Tilgass, Ē., Dinevičs, J., Gorbunovs, A. (2006). Latvija — PSRS karabāze. Rīga: Zelta grauds. 
Upmalis, I., Tilgass, Ē., Stankevičs, E. (2011). Latvija padomju militāristu varā. 1939-1999. Rīga: Latvijas okupācijas izpētes biedrība.

Vītols, K. (1965) Latvijas PSR kriminālkodeksa 59-84(1) pantu komentārs. Latvijas PSR kriminālkodeksa komentāri. Rīga: Liesma, 144 - 187.

VZD Latvijas 1. etapa ortofoto karšu mozaīka. LU G̦ZZF karšu pārlūks. Pieejams http://kartes.geo.lu.lv/karte/ (26.01.2018.)

Watt, D. (2005). Soviet military mapping. Sheetlines, 74, 9 - 12.

Zelmenis, G. (2015). Valsts drošības komiteja un divdesmitā gadsimta astoṇdesmito gadu politiskās represijas okupētajā Latvijā: izpētes iespējas. Totalitārisma sabiedrības kontrole un represijas (ziņojumi starptautiskajā zinātniskajā konferencē "Totalitārisma sabiedrības kontrole un represijas: dokumentu izpēte un tās metodoloǵija” 2015. gada 15.-17. decembrī Liepājā). Jarinovska K. (red.) VDK zinātniskās izpētes komisijas raksti, 1. sēj. Rīga: LPSR Valsts drošības komitejas zinātniskās izpētes komisija, Latvijas Universitātes Latvijas vēstures institūts, elektroniskais izdevums, 72 - 115.

\section{Summary}

Questions about the Soviet military heritage objects, their military significance, their inclusion and their use in contemporary context are widely discussed in the scientific literature, however, the declassified sources available in Latvia do not cover the specialization of different military objects during the Cold War. Various sources of information about the military infrastructure of the USSR during the Cold War information published in open publications, published and classified statistics, USSR military (General Staff) topographic maps, US intelligence declassified sources etc. are evaluated.

The paper concludes that in the light of restrictions on censorship, materials published in Sovietera printed materials do not contain important information that could be used to assess the scale of the military sphere of the USSR and the impact of the military sector on economic development. Soviet-era USSR General Staff topographic maps do not fully cover information on the location of Soviet military installations. Significant sources for USSR military infrastructure research are US intelligence information, orthophoto images of Latvia and a topographic map of Latvia in the scale of 1:10 000. 